\title{
Exploring Affective Factors Influencing Spoken English Teaching in College
}

\author{
Liyan $\mathrm{He}$ \\ Foreign Language Department \\ Langfang Teachers' University \\ Langfang, Hebei, China \\ E-mail: liyanhe619@163.com
}

\begin{abstract}
The article explains the definition of affect, categories of affective factors and puts forward some measures of cultivating positive affect and reducing negative affect in spoken English teaching. It greatly contributes to improving students' oral English in college.
\end{abstract}

Keywords-affective factors; spoken English; motivation

\section{INTRODUCTION}

It is well known that English is regarded as a world-wild language, which plays an essential role in international communication. Since the language is an important tool in the society, language education has to develop as quickly as possible to keep pace with the advanced society. However, spoken English in college fail to meet the requirements of the society to some degree. The reasons will be illustrated in the following parts. On the one hand, with the prevalence of examination-oriented education, most of college students pay more attention to many kinds of examination, such as CET-4, CET-6. In their eyes, high mark is the number one. On the other hand, many English learners are afraid of speaking English for one reason or another. For one thing, some Chinese learners are very shy and nervous, which is a great obstacle to language learning. They dare not speak English before the whole class. For another, they are afraid of making mistakes. As a result, "dumb English" comes into being. However, teachers are capable of helping students reduce the psychological pressure when they learn English and get rid of anxious feelings. The article explores the affective factors in spoken English teaching in college.

\section{BASIC KNOWLEDGE OF AFFECTIVE FACTORS}

\section{A. Definitions of Affect}

Many researchers are inclined to explore the affect. While different researchers have different definitions on the term of "affect". What is affect? Generally speaking, affect is commonly defined as the area covering feelings, emotions, mood and temperament.

Linguists Jane Arnold and H. Douglas Brown define affect like this: "Affect is considered as aspects of emotion, feeling, mood or attitude which condition behavior" (Arnold 22). According to Krashen, one's "affect" towards a particular thing or action or situation or experience is how that thing that action that experience fits in with one's needs or purpose, and its resulting effect on one's emotions (85). The emotion along with needs and purposes is not surprising when one consider that emotions are commonly responses to how one's various needs and purposes are not being met. The present author would combine the believe affect implies a wide range of concepts and phenomena including feelings, emotions, moods, needs and tendencies.

Although each researcher has his definition on "affect". However, different definitions have the same tendency. To say it frankly, during spoken English teaching, affect is referred to emotion, feeling, mood or attitude and so on, which are the affective condition among teacher, students and English teaching material in the process of English teaching and learning. It will influence both learning behavior and result directly.

\section{B. Categories of Affective Factors}

Affective factors can be referred to one's emotional experience and sentimental reflection when one faces some phenomena of happiness and anger. Psychological research shows that affective factors directly influence foreign language learning behavior and results to a large degree. They may have a great effect on oral English learning, such as self-esteem, attitude, inhibition, tension and so on. Affective factors can be divided into two categories: positive affective factors and negative affective factors. Positive affective factors include motivation, attitude, self-esteem, which stimulate students to actively take part in the conversational class and try their best to speak English as well as possible. In the thesis, motivation is mainly concerned. On the contrary, negative affective factors, such as anxiety, inhibition, nervousness, can prevent learners from bringing their potentials into play and affect learning results. Anxiety is paid much attention to in the thesis. Foreign language anxiety is considered as "a distinct complex of selfperceptions, believes, feelings, and behaviors related to classroom language learning process" (Horwitz 128). 


\section{APPLICATION OF AFFECTIVE FACTORS IN SPOKEN ENGLISH TEACHING}

From the foregoing, motivation includes intrinsic motivation and extrinsic motivation. River (69) claims that intrinsic motivation is clearly superior to extrinsic motivation. In other words, extrinsic motivation can be beneficial, while learning is most favorably influenced by intrinsic orientations, especially for long-term retention. So it is essential to take some measures to stimulate students' intrinsic motivation. The main possible ways are arousing students' interest and establishing students' self-confidence.

\section{A. Arousing Students' Interest}

Interest is the emotional reflection when a person realizes that he needs something and it reflects a person's attitude towards choosing an objective thing. Learners with strong interest in English learning can perform perfectly and get the best results, and they can bring all their language competence into full play in learning. Because of the function of interest, English teacher should pay more attention to train and maintain the students' interest of English learning through changing teaching methods, renewing the teaching concept. During the process of English teaching, students not only acquire rich knowledge, but also experience infinite happiness. Adopting diversified teaching methods is one of effective ways to stimulate students' interest. More importantly, students will be more interested in the subject. There are many English activities including role-play, English debate, English speaking contests, English songs and English word twisters and so on. Especially, the role-play plays an important part in spoken English teaching. For example, when the topic is related to marriage and generation gap, a teacher can make a role-play activity named "the principle of being father and mother". In the activity, girls and boys can play different roles such as father, mother and children. It is certainly that they may communicate with each other on the matter of family. Thus, the students can experience the problems in family life through group cooperation and presentation, and express their own ideas freely. During this process, students may feel excited to talk in English. These activities can offer more chances for each student to express himself freely. What's more, the English contest is a really good platform for English learners to practice oral English. College students who come from different English levels get together to exchange unique views on certain topic and develop their oral English.

\section{B. Establishing Students' Self-confidence}

Self-confidence is also an extremely essential factor in stimulating students' intrinsic motivation, even though interest is very important. As one of affective factors, selfconfidence also plays an essential role in English speaking teaching and learning, which is regarded pervasively as an active emotional factor in one's process of language learning. Brown considers that at the heart learning is the condition that a person believes in his or her own ability to accomplish the task. In other words, confident students dare to take all kinds of risks and make conversations and express their own points of view bravely in English without any hesitation. They can easily seize more opportunities to practice their oral English bravely and generously. However, those who lack of confidence may fail to make their potential into play even though he has the language competence to speak English very well. Lacking of confidence is a psychological obstacle in foreign language learning. It is necessary to adjust their state of mind when teaching English. "Therefore, it is very important for the teacher to create a relaxed and supportive environment and help them build up their confidence" (Wang, 159-60).

- Experience the sense of success. In the teaching process, the teacher should prepare lessons carefully and take measures to fit the students with different levels. So teacher should set different targets for different students and let each student be able to experience the successful fun. In other words, teacher should think over individual difference of everyone and offer more opportunities to perform themselves before the whole class. So effective teachers know how to adjust the level of difficulty of learning for particular students, this means providing special challenge for the brightest in the class and providing more assistance for whose who find a particular task too difficult. For instance, teacher should not let a student with poor oral English introduce the history of Harvard University without any preparation, because the history of it refers to many details, such as exact times, location, historic background. That is a great challenge for students who are not good at expressing themselves in English. Thus, teacher fails to establish students' self-confidence; even destroy students' self-esteem seriously. However, if the question is designed properly, all students could not only taste the joy of success, but also show their talents. Moreover, their self-confidence will be increased greatly.

- Allow students make mistakes, such as inexact pronunciation and wrong grammar structure in the process of English learning, because it is inevitable to make mistakes. Then teacher ought to correct the answer patiently and explain the reason gently instead of criticizing student seriously. If criticism comes from teacher frequently, the self-confidence of students will be destroyed gradually day after day. More seriously, students lose interest in both teacher and the subject, which greatly influence their learning results. Teacher should encourage them timely, such as "That is a good idea", "You have made great progress", "The answer is wonderful" even though the answer is not ideal. Students' confidence will be built up in this way day after day. More importantly, students can experience the sense of security and belonging.

\section{Reducing Students' Anxiety in Spoken English Teaching}

As stated above, it is very effective to cultivate students' positive affective factors in spoken English teaching. While the following section will put forward some measures to 
reduce students' negative factors. Anxiety is a negative factor that hinders foreign language speaking. "Anxiety is the largest barriers in learning" (Arnold 58). It is associated with negative feelings, such as nervousness, self-doubt, worry and sense of frustration. As a matter of fact, it is a kind of subjective feeling, especially when learners engage in a foreign language learning owing to lacking of confidence, feeling of upset and anxiety come into being. It easily leads to nervousness, tension, seriously reducing selfconfidence and motivation. Seriously, it can affect one's learning result. So it is indispensable to create a harmonious and relaxed climate for learners to achieve great achievements during the English conversational class. There are two important ways to diminish anxiety: creating a harmonious atmosphere and improving their whole language competence.

First, harmonious classroom atmosphere refers to a relaxed and pleasant situation in the class, which is useful to reduce learners' anxiety. Therefore, teacher should try his best to create a relaxed atmosphere and build an equal relationship in which students are willing to learn, free to practice their English with lower anxiety. Different learners have different needs for English conversational class. More importantly, the real need of students must be known clearly by teacher. Teacher may spend a lot of time on communicating with students and understanding their real inner world. For instance, during the period of the rest, teacher should actively talk with students to gain some information about their hobbies, lives and study, which easily help them to mutual understand each other. Under the circumstance, students are willing to exchange their points of view with teacher and classmates without feeling anxious and nervous. What's more, teacher has the responsibility to provide more opportunities for learners to practice their oral English. For instance, students may spend five to ten minutes on reporting the news about the earthquake before the class. By the way, anything can be taken as material, which depends on students' interest. Then teacher may organize the whole class to discuss the reason and the situation of certain place. Students may guess and express their views freely. The situation of classroom will be active. It is effective to reduce students' anxiety and encourage them to express themselves in English bravely under the circumstance. Only in this way, can students cooperate with teacher actively and take part in different discussion under the relaxed, free and pleasant environment. Besides, mutual action between teachers and students is also very important for college students. Teacher must guarantee enough time for learners to take part in the teaching activity in each class and avoid some unnecessary scold and blame. Teacher needs to seize any chance to contact with students. They can understand mutually and narrow the psychological distance by the conversation. Besides, teacher has to care, love and encourage each student. In such cases, students will feel real progress, get the sense of success and at last reduce the anxiety of English. With this kind of comfortable surroundings, students will feel more relaxed and they will present their own opinions towards some issues more freely. What's more, by this way, students are easier to digest the knowledge what they have learned in class.
Second, English is composed of listening, speaking, reading, writing and translating. They are connected with each other. If students are superior in every aspect of English, they will be confident without any anxiety. Oral English teacher should pay more attention to improving learners' ability of reading, listening and writing. What's more, it is essential to offer some instructive methods for them, such as listening news, reading magazine and writing diaries in English frequently. If their English could be improved greatly, they will express their inner world activity in English instead of anxiety. By the way, they are more confident and brave to show their beautiful English in language conversational class. Then teacher helps them to correct answer gently instead of criticizing seriously. It is granted to praise students properly even though they have made a little progress, which can boost their self-esteem and selfconfidence. As time goes, they may give up anxiety but speak English confidently.

\section{Improving Teacher's Full-developed Abilities}

"Teacher's behavior makes a potential influence on student's spirit" (Tang, 57). Therefore, the impression of an English teacher has a great effect on students' learning behavior and result. Namely, students are interested in a subject just because they worship the teacher's personality or extensive knowledge. As a good English teacher he must improve his full-developed abilities. Fluent language, standard pronunciation, and beautiful intonation are basic professional qualities. If an English teacher can achieve these qualities, he must be a successful and perfect example in the eyes of the learners. As a result, students may like to cooperate with teacher to finish the teaching task smoothly.

In addition, as a teacher who does not love students can never become an outstanding teacher. The expectations and love of a teacher will have a tremendous influence on motivation and inspiration of students' spirit of learning. On one hand, teacher should love, understand, trust and respect students. On the other hand, teacher is required to treat students strictly, guide students in the right direction and maintain their dignity in any case. In the class, teacher must exam his own emotion, listen to the students carefully, let them talk about their anguish and difficulties, consult with students, train students to become optimistic. Meanwhile, teacher should listen to the students' views about the teaching that are insufficient in class and make up for the insufficiencies timely. What's more, teacher wants to make friends with students if only he get out from the role of highranking commanders, such as playing game and chatting with students. By establishing an equal relationship with students, teacher can design teaching work from the perspective of students.

\section{CONCLUSION}

In the 21st century, learning English well is of realistic and far-reaching historic significance to Chinese. At present, more and more Chinese are aware of the essentiality of learning English, but the actuality of spoken English does not satisfy the needs of economic construction and social development owning to "dumb English" in college to some 
extent. Therefore, there still exists a gap between the actuality and the requirements of the fast developing age. This makes it necessary to consider the existing problems in the process of spoken English teaching and learning in college.

Affective factors play indispensable roles in oral English teaching and learning. They can greatly influence learners' process and results. While a teacher is training conversational skill, he or she should adopt a variety of methods to stimulate students' learning motivation. In addition, students' negative emotions, such as fear, worry and anxiety in the language classroom are to be cured by the use of affective and behavioral strategies. In order to teach more efficiently, it is necessary for teacher to guide learners to develop their positive affective factors and try to avoid the negative ones. Frankly speaking, it is effective to improve learners' oral English through stimulating students' motivation and reducing learning anxiety. Then the psychological distance between teacher and students will be narrowed in the harmonious classroom. Meanwhile, it can enrich teacher's professional qualities and enhance teaching effects, which greatly promote the development of the English teaching to meet the needs of the modern society.

Because of the limited time and capability, current study on the roles of affective factors in the spoken English teaching should be further explored. Future research on this topic should be considered the interaction between students' negative emotion-coping strategies and characters of the language classroom.

\section{REFERENCES}

[1] Arnold, Jane, ed. Affect in Language Learning. Beijing: Foreign Language Teaching and Research Press, 2000.

[2] Brown, H. D. Principles of Language Learning and Teaching. 3rd ed. Beijing: Foreign Language Teaching and Research Press, 2001.

[3] Krashen, S. D. Principles and Practices of Second Language Acquisition. Oxford: Oxford University Press, 1982.

[4] Horwitz, E. K., and Young, D., eds. Language Anxiety: From Theory and Research to Classroom Implication. Englewood Cliffs: Prentice Hall, 1991.

[5] Rivers, W. M. Teaching Foreign Language Skill. 2nd ed. America: The University of Chicago Press, 1981.

[6] Qiang Wang, A Course in English Language Teaching. Beijing: Higher Education Press, 2006.

[7] Songlin Tang, Research on Teachers' Act. Hunan: Hunan Normal University Press, 2002. 